\title{
Antioxidant and cytotoxic properties of protein hydrolysates obtained from enzymatic hydrolysis of Klunzinger's mullet (Liza klunzingeri) muscle
}

\author{
Sana Rabiei ${ }^{\circledR 1}$, Masoud Rezaei ${ }^{1 *}$, Samira Asgharzade², Mehdi Nikoo³, Mahmoud Rafieia-kopai ${ }^{4 *}$ \\ ${ }^{1}$ Department of Seafood Processing, Faculty of Marine Sciences, Tarbiat Modares University, Noor, Iran, ${ }^{2}$ Cellular and \\ Molecular Research Center, Basic Health Sciences Institute, Shahrekord University of Medical Sciences, Shahrekord, Iran, \\ ${ }^{3}$ Department of Pathobiology and Quality Control, Artemia and Aquaculture Research Institute, Urmia University, Urmia, \\ Iran, ${ }^{4}$ Medical Plants Research Center, Basic Health Sciences Institutes, Shahrekord University of Medical Sciences, \\ Shahrekord, Iran
}

\begin{abstract}
Today, consumers are looking for functional foods that promote health and prevent certain diseases in addition to provide nutritional requirements. This study aimed to evaluate the antioxidant and cytotoxic properties of Liza klunzingeri protein hydrolysates. Fish protein hydrolysates (FPHs) were prepared from L. klunzingeri muscle using enzymatic hydrolysis with papain at enzyme/substrate ratios of 1:25 and 1:50 for 45, 90 and $180 \mathrm{~min}$. The antioxidant activities of the FPHs were investigated through five antioxidant assays. The cytotoxic effects on $4 \mathrm{~T}_{1}$ carcinoma cell line were also evaluated. The amino acid composition and molecular weight distribution of the hydrolysate with the highest antioxidant activity were determined by HPLC. All six FPHs exhibited good scavenging activity on ABTS $\left(\mathrm{IC}_{50}=0.60-0.12\right.$ $\mathrm{mg} / \mathrm{mL}), \mathrm{DPPH}\left(\mathrm{IC}_{50}=3.18-2.08 \mathrm{mg} / \mathrm{mL}\right)$, and hydroxyl $\left(\mathrm{IC}_{50}=4.13-2.07 \mathrm{mg} / \mathrm{mL}\right)$ radicals. They also showed moderate $\mathrm{Fe}^{+2}$ chelating capacity $\left(\mathrm{IC}_{50}=2.12-12.60 \mathrm{mg} / \mathrm{mL}\right)$ and relatively poor ferric reducing activity (absorbance at $70 \mathrm{~nm}=0.01-0.15,5 \mathrm{mg} / \mathrm{mL}$ ). In addition, all hydrolysates showed cytotoxic activities against the $4 \mathrm{~T}_{1}$ cells $\left(\mathrm{IC}_{50}=1.62-2.61 \mathrm{mg} / \mathrm{mL}\right) .94 .6 \%$ of peptide in hydrolysate with the highest antioxidant activity had molecular weight less than 1,000 Da. L. klunzingeri protein hydrolysates show significant antioxidant and anticancer activities in vitro and are suggested to be used in animal studies.
\end{abstract}

Keywords: Antioxidant activity. Cytotoxic effect. Protein hydrolysate. Liza klunzingeri.

\section{INTRODUCTION}

In biological systems, free radicals are typically derived from the oxygen, nitrogen, and sulfur molecules. Due to their unpaired electrons, free radicals exhibit a great deal of combination desire for reaction with other molecules. The most important free radical including Reactive Oxygen and Nitrogen Species (ROS/RNS) are naturally produced by various metabolic pathways such as the aerobic metabolism in mitochondrial respiratory chain, and play numerous physiological roles such as intracellular signaling, regulation of cell proliferation

\footnotetext{
*Correspondence: M. Rafieia-kopai. Medical Plants Research Center, Basic Health Sciences Institutes, Shahrekord University of Medical Sciences, Shahrekord, Iran. Tel: +98 3813346692 / Fax: +98 381 3330709. E-mail: rafieian@skums.ac.ir/rafieian@Yahoo.com. M. Rezaie. Department of Seafood Processing, Faculty of Marine Sciences, Tarbiat Modares University, Noor, Iran. Tel: +98 11 44553366, Fax: +98 11 44553499. E-mail:rezai_ma@modares.ac.ir
}

and apoptosis, induction of gene expression, and ion transferring (Sarmadi, Ismail, 2010).

However, excessive production of these compounds under certain conditions can exert harmful effects by causing oxidative damage to important cellular structures. The ROS and RNS radicals react with nucleic acids, the side chains of amino acid in proteins, and double bonds of unsaturated fatty acids, triggering and developing oxidative stress, which plays an important role in the pathogenesis of many human diseases, including cancer (Nikoo, Benjakul, 2015). ROS contribute to tumor development and progression through two possible pathways inducing mutation of key gene and/or alterations of signaling and transcriptional pathways. When the cell with oxidized or otherwise modified DNA is divided, its metabolism and proliferation are impaired and a mutation occurs which is an important factor for carcinogenesis. In addition, products of lipid peroxidation can react with 
metal ions and produce active compounds, such as epoxide and aldehyde, which cause mutations in the DNA of cells (Noda, Wakasugi, 2001).

Today, researchers have proven that daily diets play an important role in preventing, developing, and treating various types of cancers. The consumption of foods rich in natural antioxidants, such as vitamins $\mathrm{E}$ and $\mathrm{C}$, can prevent the development of certain cancers by inhibition of free radicals and ROS (Terry et al., 2000; Venugopal, 2008). Increased concerns about the association between health and diet have led to growing consumer demand for the health-promoting and functional foods. Functional foods are defined as food products that provide health benefits in addition to meeting basic nutritional needs of the body (Shahidi, Alasalvar, 2011). The global functional foods market size was 299 billion dollars in 2017 and is expected to reach 441 billion dollars in 2022 (Menrad, 2003).

Marine animals, that comprise about half of the world's biodiversity, provide a valuable source of bioactive and functional compounds. Some of these compounds have a proteinaceous nature and includes proteins, peptides, and amino acids. Marine animals, in addition to being an important source of high-quality protein, are also used as the raw material for production of physiologically important peptides (Raghavan, Kristinsson, Leeuwenburgh, 2008). Bioactive peptides are specific protein fragments which remain inactive within the sequence of their parent protein until released by enzymatic hydrolysis (Harnedy, FitzGerald, 2012). Bioactive peptides derived from marine animal using enzymatic hydrolysis exhibit numerous physiological functions such as immunomodulatory, antimicrobial, anxiolytic, and hypotensive activity (Giri, Ohshima, 2012; Kumar, Nazeer, Jaiganesh, 2011).

According to the FAO, the total catch amount of Mugilidae species from southern and southwestern waters of Iran was 9300 tons in 2017 and Klunzinger's mullet (Liza klunzingeri) capture comprise about 2950 tons of this amount (FAO, 2016). Klunzinger's mullet is an inexpensive and low-value fish due to its small size and the presence of a dark brown to black peritoneum (Kiabi, Abdoli, Naderi, 1999). The use of Klunzinger's mullet for the production of protein hydrolysates provide added value and allows the optimal use of marine resources that are decreasing. In this study, L. klunzingeri muscle protein was hydrolysed by papain and the antioxidant and cytotoxic effects of protein hydrolysates were studied in vitro. In addition, the molecular weight and amino acid sequence of the hydrolysate with the highest antioxidant activity was determined using HPLC.

\section{MATERIAL AND METHODS}

\section{Material}

2,2'-azinobios-(3-ethylbenzothiazoline-6-sulphonic acid) (ABTS), 2,2-diphenyl-1-picrylhydrazyl (DPPH), ferrozine (3-(2-Pyridyl)-5,6-diphenyl-1,2,4-triazine4',4"-disulfonic acid sodium salt), Dimethyl sulfoxide (DMSO), 3-(4,5-Dimethyl-2-thiazolyl)-2,5-diphenyl-2Htetrazolium bromide (MTT), Dulbecco's Modified Eagle's Medium (DMEM), Fetal Bovine Serum (FBS), Butylated hydroxytoluene (BHT), and Trypsin-EDTA solution were purchased from Sigma-Aldrich Chemical Co. (St. Louis, MO, USA). Other chemicals were purchased from Merck Co. (Germany) and were of analytical grade. Papain from papaya latex (1.5-10 units/mg Solid, $\mathrm{pH} 6.0,40^{\circ} \mathrm{C}$ ) was purchased from Sigma-Aldrich Chemical Co. (St. Louis, $\mathrm{MO}$, USA). The enzyme was stored at $4{ }^{\circ} \mathrm{C}$ until use.

\section{Methods}

L. klunzingeri proximate chemical composition: Fresh L. klunzingeri was provided from the fish market and transferred to the laboratory in ice. The fish were first washed and filleted, and the fillets were then minced and stored at $-20{ }^{\circ} \mathrm{C}$ until the experiments. In order to determine the moisture content, $2 \mathrm{~g}$ of fish mince were dried in an oven at $105{ }^{\circ} \mathrm{C}$ to reach constant weight, the moisture content was calculated by measuring the weight loss following heating. Ash content was determined by complete oxidation of organic matter at $550-600{ }^{\circ} \mathrm{C}$ in a furnace. The nitrogen of the samples was determined via the Kjeldahl method. Crude protein was calculated by multiplying the determined nitrogen content by a nitrogen-to-protein conversion factor $(\times 6.25)$. Fat content of sample was determined by AOAC Soxhlet procedures (AOAC, 1995).

\section{Preparation of protein hydrolysates}

Samples of L. klunzingeri mince $(50 \mathrm{~g})$ was placed in an Erlenmeyer flask and then $100 \mathrm{~mL}$ of phosphate buffer (pH 6) was added to keep the $\mathrm{pH}$ constant throughout the incubation time. In order to inactivate the endogenous enzymes, the samples were heated in a water bath at $85^{\circ} \mathrm{C}$ for $20 \mathrm{~min}$. After cooling, samples were hydrolyzed using papain (enzyme to substrate ratio of 1:50 and 1:25) for 45,90 and 180 at $55^{\circ} \mathrm{C}$. The hydrolysis was performed using $250 \mathrm{~mL}$ glass vessels inside a shaking water bath (SWB 15 Precision). After the incubation time, samples were heated at $95^{\circ} \mathrm{C}$ during $15 \mathrm{~min}$ to stop the enzymatic reaction. After cooling at room temperature for $15 \mathrm{~min}$, the 
samples were centrifuged $\left(8000 \times \mathrm{g}\right.$ at $10^{\circ} \mathrm{C}$ for $\left.30 \mathrm{~min}\right)$. After removing the surface oil using a micropipette, the supernatant was collected and freeze-dried at $-50^{\circ} \mathrm{C}$ under vacuum (Labconco Freeze Dryer, USA). Obtained protein hydrolysates were named $\mathrm{FPH}_{2-45}$ (E/S ratio of 1:50 and time of $45 \mathrm{~min}), \mathrm{FPH}_{2-90}(\mathrm{E} / \mathrm{S}$ ratio of 1:50 and time of $90 \mathrm{~min}), \mathrm{FPH}_{2-180}(\mathrm{E} / \mathrm{S}$ ratio of 1:50 and time of $180 \mathrm{~min})$, $\mathrm{FPH}_{4-45}(\mathrm{E} / \mathrm{S}$ ratio of 1:25 and time of $45 \mathrm{~min}), \mathrm{FPH}_{4-90}(\mathrm{E} / \mathrm{S}$ ratio of 1:25 and time of $90 \mathrm{~min})$ and $\mathrm{FPH}_{4-180}(\mathrm{E} / \mathrm{S}$ ratio of $1: 25$ and time of $180 \mathrm{~min}$ ) and stored at $-20^{\circ} \mathrm{C}$ until further analysis.

\section{$D P P H^{*}$ radical scavenging activity}

BHT and FPHs at different concentrations were prepared in distilled water. Then, $1 \mathrm{~mL}$ of sample solution was added to $1 \mathrm{~mL}$ of $0.1 \mathrm{mM}$ DPPH solution (prepared in $95 \%$ ethanol) and the absorbance of the mixture was recorded at $517 \mathrm{~nm}$ after $20 \mathrm{~min}$ of incubation in dark. The control was prepared using $1 \mathrm{~mL}$ of distilled water instead of sample. DPPH radical scavenging activity was expressed as percentage of inhibition using the following equation: \%DPPH radical scavenging activit $\mathrm{y}=[(\mathrm{Ac}-\mathrm{As}) / \mathrm{Ac}] \times 100$. Where Ac is the absorbance of control and As is the absorbance of the sample. The effective concentration of sample required to inhibits $50 \%$ of the DPPH radical ( $\mathrm{IC}_{50}$ value) was obtained by plotting a graph of concentration (X axis) versus percentage of inhibition (Y-axis) (Nikoo et al., 2014).

\section{$\mathrm{Fe}^{2+}$ chelating activity}

One $\mathrm{mL}$ of BHT or FPHs solution at different concentrations was mixed with $0.1 \mathrm{~mL}$ of $2 \mathrm{mM} \mathrm{FeCl}_{2}$ and $0.2 \mathrm{~mL}$ of $5 \mathrm{mM}$ ferrozine and the final volume of the mixture was increased to $5 \mathrm{~mL}$ with addition of distilled water. After $20 \mathrm{~min}$ of incubation, the absorbance was recorded at $562 \mathrm{~nm}$. For control sample, distilled water was used instead of the sample. $\mathrm{Fe}^{2+}$ chelating activity was calculated using the following formula. $\mathrm{Fe}^{2+}$ chelating activity $(\%)=[(\mathrm{Ac}-\mathrm{As}) / \mathrm{Ac}] \times 100$ where Ac is the absorbance of control and As is the absorbance of the sample. $\mathrm{IC}_{50}$ value was calculated from the plot of the chelating activity against the sample concentration (Nikoo et al., 2014).

\section{Ferric reducing activity}

A volume of $2 \mathrm{~mL}$ of protein hydrolysate $(5 \mathrm{mg} / \mathrm{mL})$ or BHT $(0.5 \mathrm{mg} / \mathrm{mL})$ was mixed with $2 \mathrm{~mL}$ of phosphate buffer $(0.2 \mathrm{M}, \mathrm{pH} 6.6)$ and $2 \mathrm{~mL}$ of $1 \%$ potassium ferricyanide. After incubation at $50{ }^{\circ} \mathrm{C}$ for $20 \mathrm{~min}, 2 \mathrm{~mL}$ of $10 \%$ Trichloroacetic acid (TCA) was added to the mixture. Following centrifugation at $3000 \mathrm{rpm}$ for $10 \mathrm{~min}, 2 \mathrm{~mL}$ of the supernatant was mixed with $2 \mathrm{~mL}$ of distilled water and $0.5 \mathrm{~mL}$ of $0.1 \% \mathrm{FeCl}_{3}$. Then the optical absorbance was recorded at $700 \mathrm{~nm}$ (Nikoo et al., 2014).

\section{ABTS** radical scavenging activity}

The stock solution was prepared by mixing $7.4 \mathrm{mM}$ $\mathrm{ABTS}^{+}$and $2.6 \mathrm{mM}$ potassium persulfate solution $(1: 1)$ and left to incubate for $12 \mathrm{~h}$ at room temperature in the dark. Before the experiment, freshly prepared ABTS solution was diluted with methanol to reach an absorbance of $1.1 \pm 0.02$ at $734 \mathrm{~nm}$. Then, $150 \mu \mathrm{L}$ of FPHs or BHT at different concentrations was mixed with $2850 \mu \mathrm{L}$ of ABTS solution, and after incubation at room temperature for $2 \mathrm{~h}$, the optical absorbance was recorded. Control sample was prepared using $150 \mu \mathrm{L}$ of distilled water instead of sample. ABTS scavenging activity was determined using the following formula. ABTS scavenging activity $(\%)=[(\mathrm{Ac}-\mathrm{As}) / \mathrm{Ac} \times 100]$; where Ac is the absorbance of control and As is the absorbance of the sample. $\mathrm{IC}_{50}$ value was determined from the plot of the scavenging activity against the sample concentration (Nikoo et al., 2014).

\section{Hydroxyl radical scavenging activity}

Briefly, 1, 10-phenanthroline solution $(1.865 \mathrm{mM}$, $1 \mathrm{~mL}$ ) and FPHs or BHT at different concentrations were added into a tube and mixed. Then, $1 \mathrm{~mL}$ of the $\mathrm{FeSO}_{4}$ solution $(1.865 \mathrm{mM})$ was added to the mixture and the reaction was initiated by adding $1 \mathrm{~mL}$ of $\mathrm{H}_{2} \mathrm{O}_{2}$ $(3 \% \mathrm{v} / \mathrm{v})$. After incubation at $37^{\circ} \mathrm{C}$ for $60 \mathrm{~min}$ in a water bath, the absorbance was recorded at $536 \mathrm{~nm}$. Solution containing protein hydrolysis without hydrogen peroxide was considered as Blank and solution without protein hydrolysis was considered negative control. Hydroxyl radical scavenging activity was determined using the following formula. Hydroxyl radical scavenging activity $(\%)=[(\mathrm{As}-\mathrm{An}) /(\mathrm{Ab}-\mathrm{An})] \times 100$; where As is the absorbance of sample, An is the absorbance of the negative control and $\mathrm{Ab}$ is the absorbance of blank. $\mathrm{IC}_{50}$ value was determined from the plot of the scavenging activity against the sample concentration (Nikoo et al., 2014).

\section{Evaluation of cytotoxic effects}

MTT is a yellow water-soluble tetrazolium salt. It is reduced in the mitochondria of viable cells to generate 
a water-insoluble formazan salt. The MTT assay is a colorimetric method that evaluates the activity of cellular enzymes, in which yellow tetrazolium is converted to purple formazan. The assay is used to evaluate the proliferation of cells and the cytotoxic effects of drugs. $4 \mathrm{~T}_{1}$ carcinoma cells line was purchased from National Cell Bank of Iran (Pasteur Institute., Tehran, Iran) and cultured in DMEM medium containing 10\% FBS. After reaching around $80 \%$ confluence, they were detached by trypsin/EDTA and the number of cells was counted using a homocytometric lam. Then, $200 \mu \mathrm{L}$ of suspension containing $15 \times 10^{3}$ cells was added to each well of a 96-well plate. In the next step, the cells were treated with FPHs/carboplatin at different concentration for 48 hours. After removing the medium of the well and washing by PBS, $60 \mu 1$ of MMT solution in PBS was added to each well. The cells were then incubated at $37{ }^{\circ} \mathrm{C}$ in $5 \% \mathrm{CO}_{2}$ for 4 hours. After incubation, the medium was removed from the wells and $150 \mu \mathrm{L}$ of DMSO was added to each well. The plate was then incubated for 30 minutes at $37^{\circ} \mathrm{C}$ in the dark. Finally, the plates' absorbance was read at $570 \mathrm{~nm}$ using an ELISA reader. The percentage of cytotoxicity was calculated by the formula below:

Percentage of cell cytotoxicity $=\left[1-\frac{O D_{\text {sample }}-O D_{\text {blank }}}{O D_{\text {control }}-O D_{\text {blank }}}\right] \times 100$

\section{$I_{50}$ value determined from the plot of the scavenging activity against the sample concentration}

\section{Determination of molecular-weight distribution}

The molecular weight distribution of the hydrolysate with the highest antioxidant activity was determined by gel permeation chromatography using HPLC system (Agilent 1100, USA). A TSK gel 2000 SWXL $(300 \times 7.8 \mathrm{~mm})$ column (Tosoh, Tokyo, Japan) was equilibrated with acetonitrile: water $(40: 60, \mathrm{v} / \mathrm{v})$ in the presence of $0.1 \%$ trifluoroacetic acid (TFA). The absorbance was monitored at $225 \mathrm{~nm}$ with flow rate of $0.5 \mathrm{~mL} / \mathrm{min}$. Cytochrome C (12384 Da), bacitracin (1422 Da), Gly-Gly-Try-Arg (451 Da), and Gly-Gly-Gly (189 Da) were used as protein molecular weight standards. The logarithm of molecular weight tested and the respective retention time was shown in a linear relationship. The equation $\sum(\mathrm{Mn} \times \mathrm{Ai}) / 100$ was used to calculate the average molecular weight of sample (Guo et al., 2013).

\section{Determination of the amino acid composition}

Amino acids were determined according to the AOAC method with some modifications. One hundred and twenty milligrams of the hydrolysate powder were digested with $8 \mathrm{~mL}$ of $6 \mathrm{M} \mathrm{HCl}$ at $110{ }^{\circ} \mathrm{C}$ for 22 hours under nitrogen atmosphere. After cooling, $4.8 \mathrm{~mL}$ of $10 \mathrm{M}$ $\mathrm{NaOH}$ was added, the volume was made up to $25 \mathrm{~mL}$ with distilled water, then filtered through two layers of filter paper No. 40, and finally centrifuged at $10,000 \mathrm{~g}$ for $10 \mathrm{~min}$. Amino acids were analyzed by using the reverse-phase high performance liquid chromatography (Agilent 1100 HPLC; Agilent Ltd., Palo Alto, CA, USA). Each sample $(1 \mu \mathrm{L})$ was injected into a Zorbax, 80A C-1 8 column (column size: $4.0 \times 250 \mathrm{~mm}, 5 \mu \mathrm{m}$ particle size; Agilent, USA) at $40{ }^{\circ} \mathrm{C}$ with detection at $338 \mathrm{~nm}$. The mobile phase A was $7.35 \mathrm{mM} / \mathrm{L}$ of sodium acetate/triethylamine/ tetrahydrofuran (500:0.12:2.5, v/v/v), adjusted to $\mathrm{pH} 7.2$ using acetic acid, while the mobile phase $\mathrm{B}(\mathrm{pH} 7.2)$ was $7.35 \mathrm{mM} / \mathrm{L}$ of sodium acetate/methanol/ acetonitrile $(1: 2: 2, \mathrm{v} / \mathrm{v} / \mathrm{v})$. The amino acid composition was expressed as grams of amino acids per $100 \mathrm{~g}$ of protein (Guo et al., 2013).

\section{Statistical analysis}

Data were analyzed using SPSS version 20. Analysis of Variance (ANOVA) followed by Duncan's test used to identify statistical differences between means. All data were presented as mean \pm SD and $p$ value less than 0.05 was considered statistically significant.

\section{RESULTS AND DISCUSSION}

Figures 1-3 show the antioxidant activities of BHT and FPHs made by enzymatic hydrolysis of L. klunzingeri muscle protein. As shown BHT showed strong DPPH, ABTS and hydroxyl radicals scavenging activities (IC50 values of $0.047 \pm 0.01,0.021 \pm 0.009$ and $0.24 \pm 0.02 \mathrm{mg} / \mathrm{mL}$ respectively), $\mathrm{Fe}^{2+}$ chelating capacity (IC50 value of $0.057 \pm 0.01 \mathrm{mg} / \mathrm{mL}$ ) and ferric reducing activity (optical absorbance of $1.16 \pm 0.09$ at $700 \mathrm{~nm}$ wavelength). Protein hydrolysates obtained by enzymatic hydrolysis of $L$. kludingeri muscle using two concentration of papain at 45,90 , and $180 \mathrm{~min}$, exhibited good scavenging activity on DPPH $\left(\mathrm{IC}_{50}=2.08-3.18 \mathrm{mg} / \mathrm{mL}\right)$, $\operatorname{ABTS}\left(\mathrm{IC}_{50}=0.12-0.60 \mathrm{mg} / \mathrm{mL}\right)$, and hydroxyl $\left(\mathrm{IC}_{50}=2.07-4.13 \mathrm{mg} / \mathrm{mL}\right)$ radicals, moderate chelating activities on $\mathrm{Fe}^{2+}\left(\mathrm{IC}_{50}=2.12-12.60 \mathrm{mg} / \mathrm{mL}\right)$, and relatively poor ferric reducing activities (optical absorbance of 0.01-0.15 at $700 \mathrm{~nm}$ wavelength). With increasing the hydrolysis duration and the concentration of papain, the antioxidant activities of the FPHs in inhibiting the DPPH, ABTS, and hydroxyl radicals were increased, so that the highest inhibitory activity obtained for the $\mathrm{FPH}_{4-180}$ with $\mathrm{IC}_{50}$ values of $2.08 \pm 0.13,0.12 \pm 0.01$, and $2.07 \pm 0.31 \mathrm{mg} / \mathrm{mL}$, 
respectively. $\mathrm{Fe}^{2+}$ - chelating activity of FPHs decreased with increasing the hydrolysis duration and $\mathrm{FPH}_{4^{-}}{ }_{180}$ sample with the highest inhibitory activity on the ABTS, $\mathrm{DPPH}$, and hydroxyl radicals showed the lowest $\mathrm{Fe}^{2+}$ chelating activity $\left(\mathrm{IC}_{50}=12.60 \pm 0.02\right)$. As shown in figure 3 , the increase of hydrolysis time increased ferric reducing activity and therefore, FPHs obtained after 90 and $180 \mathrm{~min}$ of hydrolysis demonstrated better activities than sample obtained after $45 \mathrm{~min}$ of hydrolysis.

The analysis of the molecular weight distribution of the hydrlysate with the highest antioxidant activity $\left(\mathrm{FPH}_{4-180}\right)$ by using HPLC, showed that $95 \%$ of the peptides in this sample had a molecular weight of less than 1000 Da. $30.56 \%$ of peptides in this sample had molecular

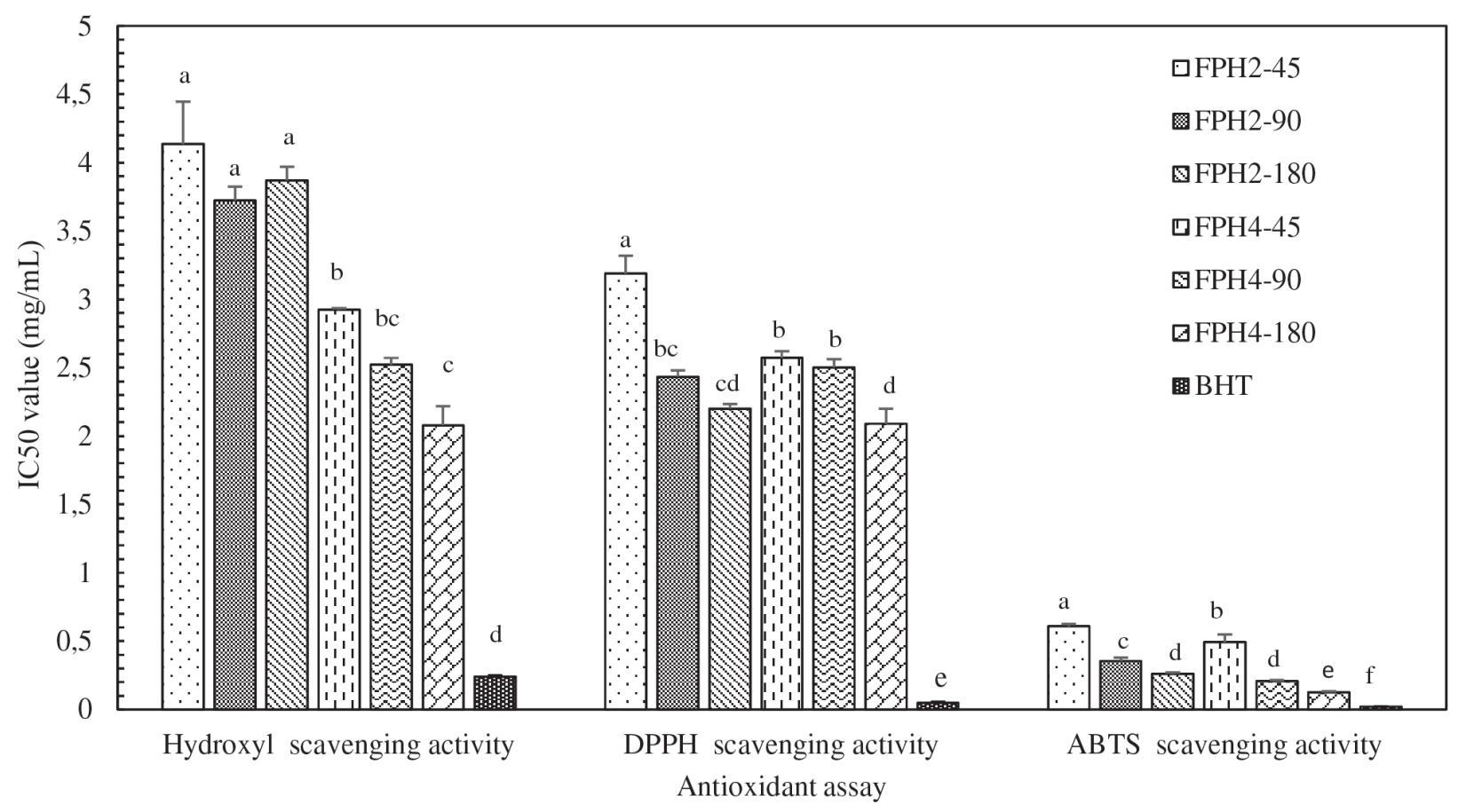

FIGURE 1 - The IC50 value of Liza klunzingeri muscle protein hydrolysates and BHT for DPPH, ABTS, and hydroxyl radicals scavenging activities. Different letters indicate statistically significant differences between antioxidant activities of samples (mean \pm SD and $\mathrm{p}<0.05)$.

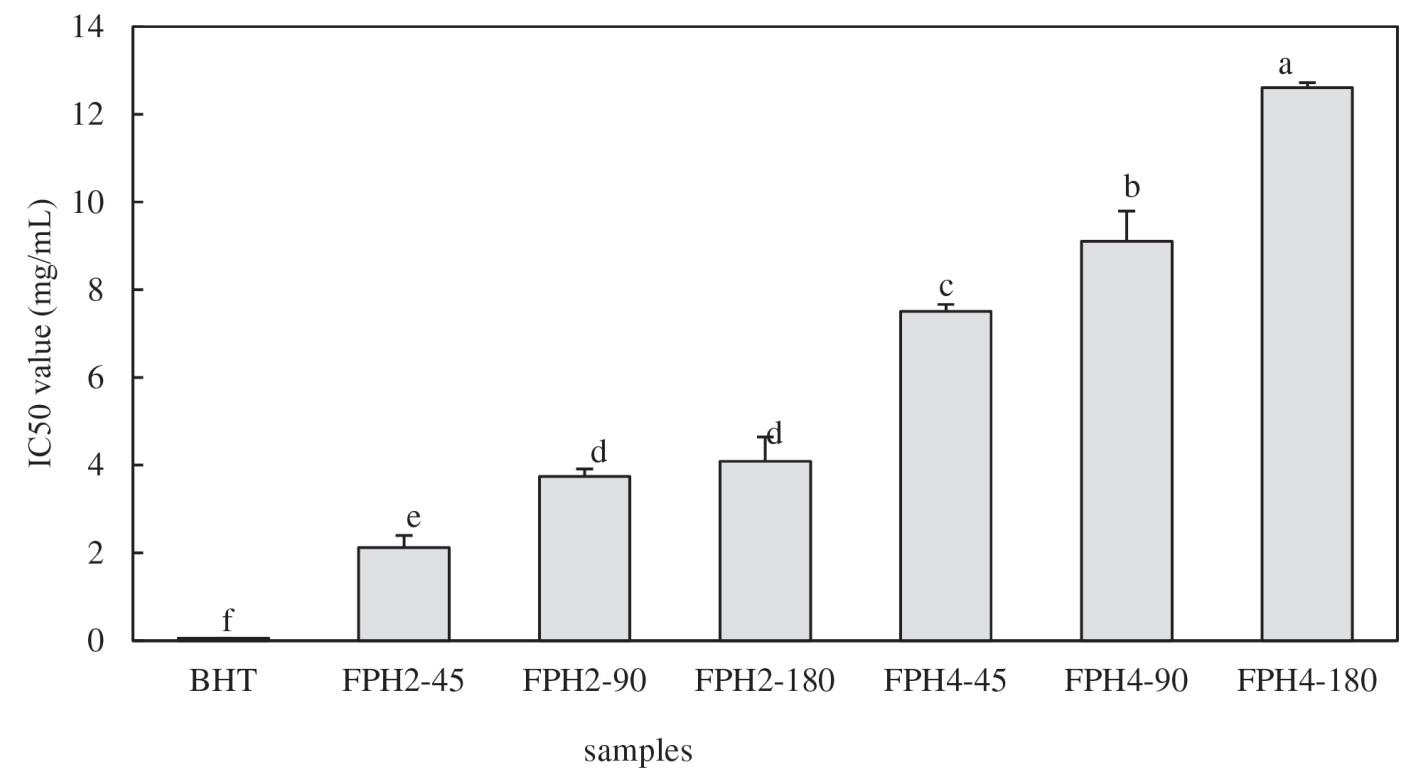

FIGURE 2 - The IC50 value of Liza klunzingeri muscle protein hydrolysates and BHT for $\mathrm{Fe}^{2+}$ chelating activity. Different letters indicate statistically significant differences between antioxidant activities of samples (mean $\pm \mathrm{SD}$ and $\mathrm{p}<0.05$ ). 


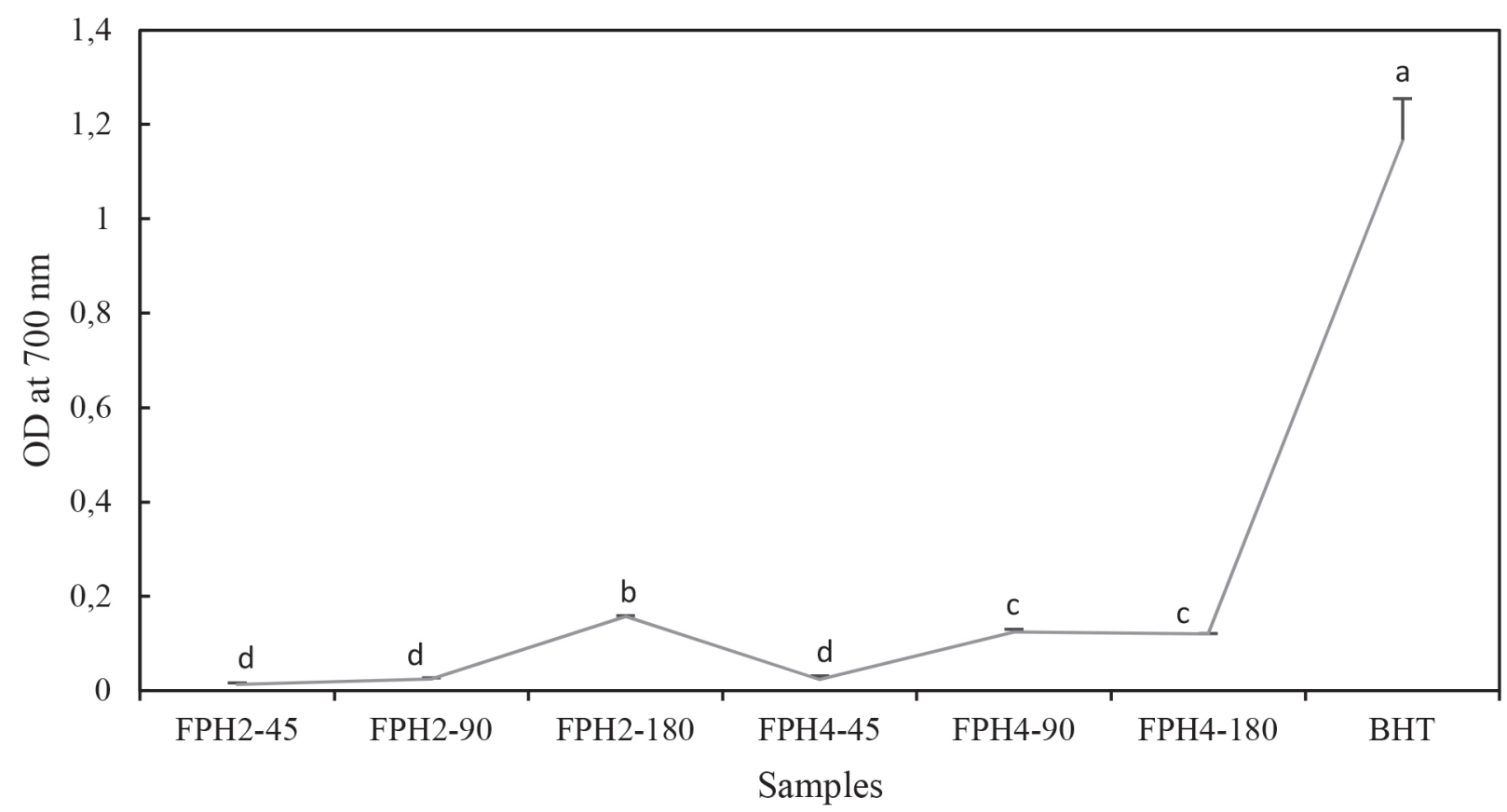

FIGURE 3 - The ferric reducing activity of Liza klunzingeri muscle protein hydrolysates and BHT. Different letters indicate statistically significant differences between ferric reducing activity of samples (mean $\pm \mathrm{SD}$ and $\mathrm{p}<0.05$ )

weight of less than $180 \mathrm{Da}, 47.26 \%$ had molecular weight of $180-500 \mathrm{Da}$, and $17.46 \%$ had molecular weight of 500-1000 Da (Figure 4).

It seems that the higher activity of $\mathrm{FPH}_{4-180}$ sample in inhibition of DPPH, ABTS, and hydroxyl radicals is due to the presence of low-molecular-weight peptides, which increased with increasing hydrolysis duration. Several studies have suggested that high degrees of hydrolysis and low molecular weight have a positive correlation with the DPPH and ABTS radical scavenging activity (Bougatef et al., 2010; Liu et al., 2010; Phanturat et al., 2010; Raghavan, Kristinsson, 2008), although some studies have reported an inverse relationship (Alemán et al., 2011a; Theodore, Raghavan, Kristinsson, 2008).

Also, in the present study, the $\mathrm{Fe}^{2+}$ chelating activities of the $\mathrm{FPH}_{\mathrm{S}}$ showed the opposite trend and $\mathrm{FPH}_{4-180}$ had the lowest $\mathrm{Fe}^{2+}$-chelating activity. In a study by Pownall, Udenigwe and Aluko (2010), the pea seed

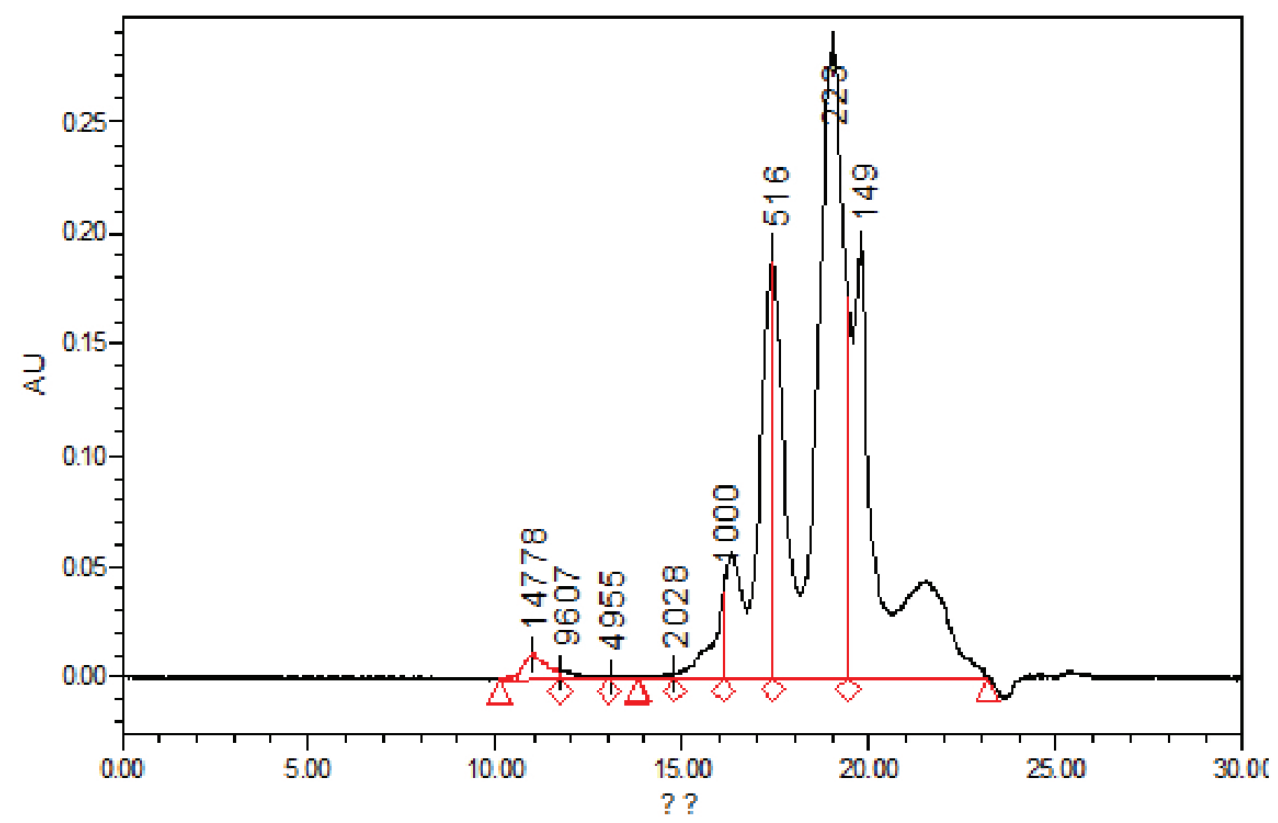

FIGURE 4 - Molecular weight distribution of Liza klunzingeri protein hydrolysate with the highest antioxidant activity. 
protein hydrolysate, which showed the highest $\mathrm{Fe}^{2+}$ chelating activity, had a poor inhibitory effect on the ABTS, DPPH, hydroxyl, and hydrogen peroxide radicals, which is consistent with our results (Pownall, Udenigwe, Aluko, 2010). Alemán et al. (2011b) argued that squid gelatin hydrolysates with a higher degree of hydrolysis and a lower molecular weight, exhibited better $\mathrm{Fe}^{2+}$-chelating activity (Alemán et al., 2011b), while Bamdad, Wu and Chen (2011) reported that peptides with a higher molecular weight exhibited higher $\mathrm{Fe}^{2+}$-chelating activity, which is due to the trapping of iron ions in the peptide chain (Bamdad, Wu, Chen, 2011).

Furthermore, we found that the ferric reducing activities of FPHs increased with the increasing the time of hydrolysis and therefore breakdown of large peptides into smaller peptide units. Contradictory results have been reported regarding molecular weight relationship with ferric reducing activity, some of which, in agreement with the present study, have shown an inverse correlation between ferric reducing activity and molecular weight (Alemán et al., 2011a), and others have indicated a positive correlation (Theodore et al., 2008).

The inconsistencies in the findings of various studies suggest that molecular weight is not the main determinant of the antioxidant activity of the protein hydrolysate and peptide samples. It has been reported that the antioxidant properties of the bioactive peptides depends on their size of peptides and also amino acid sequences, which are influenced by the source of substrate protein, type of enzyme used, enzyme to substrate ratio and hydrolysis conditions (temperature, $\mathrm{pH}$ and time) (Harnedy, FitzGerald, 2012).

In this study, the most abundant amino acids in $\mathrm{FPH}_{4}{ }^{-}{ }_{180}$ sample were serine $(9.593 \%)$, tyrosine $(8.43 \%)$, cysteine $(7.197 \%)$, valine $(6.60 \%)$, histidine $(5.81 \%)$, and glutamine $(4.914 \%)$ (Table I). It is reported that aromatic amino acids (phenylalanine, tryptophan and tyrosine) donate the electron to free radicals and make them stable molecules (Sarmadi, Ismail, 2010). Amino acids, such as histidine, leucine, tyrosine, methionine, and cysteine, neutralize free radicals by donating proton (Mendis et al., 2005), fat-soluble free radicals (peroxyl radicals) that are produced throughout the oxidation of unsaturated fatty acids are neutralized by hydrophobic amino acids such as leucine, valine, alanine, and proline (Kim, Mendis, 2006). Thus, it can be argued that natural protein hydrolysates may have inhibitory effects on several types of free radicals due to the presence of various amino acids, while purified peptide from a protein hydrolysate that contains fewer types of amino acids may exert low inhibitory effect on some free radicals. In the study on fractions derived from Cod protein hydrolysates, it was observed that the isolation of different fractions with strong DPPH scavenging effect resulted in a decrease of ferric reducing activity, which was due to an increase in the ratio of positively charged amino acids to sulfur-containing amino acids (Girgih et al., 2015).

TABLE I - Amino acid composition of Liza klunzingeri protein hydrolysates with the highest antioxidant activity

\begin{tabular}{lc}
\hline Amino acid & g/100 g pr \\
\hline Aspartic Acid & 2.93908 \\
Glutamic Acid & 4.91412 \\
Serine & 9.50344 \\
Histidine & 5.81917 \\
Glycine & 1.45979 \\
Threonine & 1.08553 \\
Arginine & 1.94127 \\
Alanin & 1.81932 \\
Tyrosine & 8.34432 \\
Cysteine & 7.01992 \\
Methionine & 1.87524 \\
Valine & 6.16082 \\
Phenylalanine & 1.11977 \\
Isoleucine & 1.45958 \\
Leucine & 2.25984 \\
Lysin & 2.64536 \\
Proline & 2.64536 \\
\hline
\end{tabular}

As shown in Figure 5, the FPHs obtained from enzymatic hydrolysis of L. klunzingeri showed significant cytotoxic activities $\left(\mathrm{IC}_{50}=1.62-2.61 \mathrm{mg} / \mathrm{mL}\right)$ on $4 \mathrm{~T}_{1}$ breast cancer cell line. The cytotoxic activities of samples decreased with increasing the hydrolysis duration and $\mathrm{FPH}_{4^{-}}{ }_{45}$ sample that was hydrolysed for a shorter period showed the highest cytotoxic activity $\left(\mathrm{IC}_{50}=1.62 \pm 0.10 \mathrm{mg} / \mathrm{mL}\right.$, Figure 5). In the study of Picot et al. (2006) the cytotoxic effects of protein hydrolysates of 18 fish species were determined on MCF-7/6 and MDA-MB-231 cancer cells, and the highest cytotoxic effect (up to $40 \%$ ) was exhibited by the Cod protein hydrolysate $(1 \mathrm{mg} / \mathrm{kg}, 72 \mathrm{~h}$ ) on the MCF-7 cell line (Picot et al., 2006). Tuna muscle protein hydrolysate also showed a significant inhibitory effect on the MCF7 cell line, and the highest inhibitory activity was obtained for the fraction with 390-1000 Da molecular weight (Hsu, Li-Chan, Jao, 2011). In a study, fraction with low MW peptides $(<3 \mathrm{kDa})$ isolated from Loach 


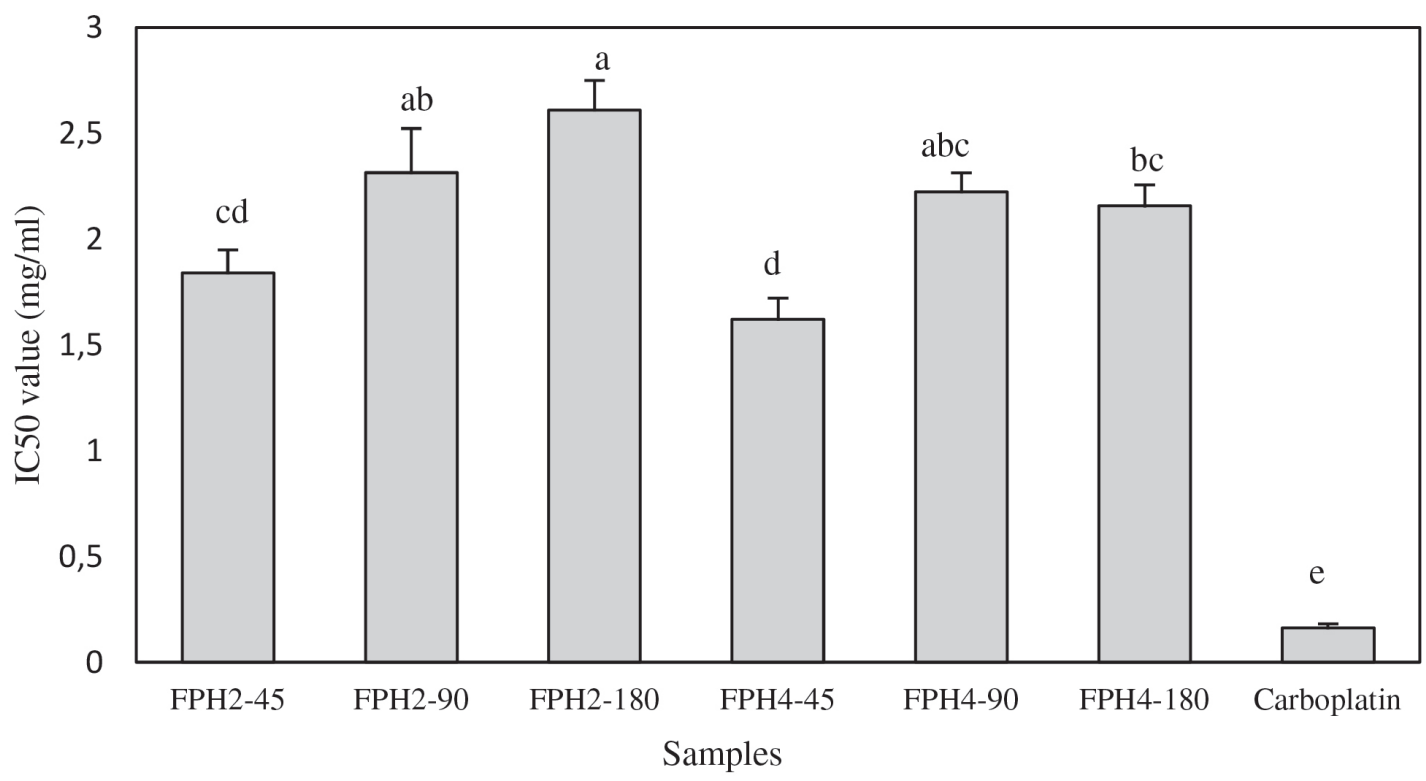

FIGURE 5 - The $\mathrm{IC}_{50}$ value of Liza klunzingeri muscle protein hydrolysates and carboplatin against $4 \mathrm{~T}_{1}$ cancer cell line. Different letters indicate statistically significant differences between antioxidant activities of protein hydrolysate samples (mean \pm SD and $\mathrm{p}<0.05)$.

protein hydrolysate showed better cytotoxicity than fractions with high MW peptides (3-5 kDa, 5-10 kDa and $>\mathrm{kDa}$ ) (Zhao, Liu, Regenstein, 2011). However, some high MW peptides derived from buckwheat seeds (approximately $4 \mathrm{kDa}$ ) (Leung, $\mathrm{Ng}, 2007$ ) and soybean protein hydrolysate $(>10 \mathrm{kDa})$ were also reported to show significant cytotoxicity (Marcela et al., 2016). Therefore, some researchers have claimed that the cytotoxicity of the peptides depends not only on the chain length, but also amino acid sequences, which are influenced by the source of substrate protein, type and amount of enzyme used, and hydrolysis conditions (Alemán et al., 2011b; Picot et al., 2006). In the present study, $64.72 \%$ of peptide in $\mathrm{FPH}_{4-180}$ sample had molecular weight distribution less than $500 \mathrm{Da}$. It seems that the molecular weight of peptides and therefore the cytotoxic activity were reduced compared to the samples hydrolysed at shorter time.

Table II shows the proximate composition of $L$. klunzingeri muscle and protein hydrolysate (with highest antioxidant activity, $\mathrm{FPH}_{4^{-}}{ }_{180}$ sample). The protein contents of L. klunzingeri muscle and protein hydrolysate were $87.84 \pm 2.85 \%$ and $22.45 \pm 3.39 \%$. This indicates that protein hydrolysate obtained from enzymatic hydrolysis of $L$. klunzingeri muscle has a high nutritive value due to the presence of high level of protein/amino acids.

In this study, however, FPHs exhibited much lower antioxidant and cytotoxic activities than do BHT and carboplatin, but they are safer to eat, causing fewer adverse effects and provide the body a rich source of high-quality protein. BHT is a synthetic antioxidant commonly used in products such as food, cosmetics and pharmaceutics, but it might exert some toxic side effects on body's tissues, leading to the development of cancer (Witschi, 1986). It was also reported that the oral administration of BHT could induce oxidative stress by interfering with oxidativeantioxidant balance (Faine et al., 2006). Carboplatin is a potent chemotherapy medication used to treat a number type of cancer but, it often causes specific side effects such as anemia, nausea, electrolyte problems, allergic reactions and increased risk of another cancer (Tothilla et al., 1992). So there is a growing trend to replace these synthetic compounds with natural ones to prevent or alleviate oxidative stress and associated diseases (Hsu, Li-Chan, Jao, 2011).

TABLE II - The moisture, total protein, fat, and ash contents of Liza klunzingeri muscle and protein hydrolysate

\begin{tabular}{ccccc}
\hline Fat & Ash & Protein & Moisture & Samples \\
\hline & & Mean \pm SD & \\
\hline $0.77 \pm 0.46$ & $9.52 \pm 0.83$ & $87.84 \pm 2.85$ & $1.87 \pm 1.72$ & P4-180 \\
$2.21 \pm 0.53$ & $2.00 \pm 0.42$ & $22.46 \pm 3.41$ & $73.36 \pm 3.90$ & Protein \\
\hline
\end{tabular}


Based on the findings of the present study, the protein hydrolysates of L. klunzingeri muscle exhibit significant antioxidant and cytotoxic properties in vitro. Besides, it has a high nutritional value because of its valuable content of protein and essential amino acid. However, in the body, peptides present in the protein hydrolysates may be metabolized due to enzymatic and digestive processes, and their structure and activates may be altered; therefore, it is recommended that the efficiency of protein hydrolysates obtained from L. klunzingeri muscle be investigated and confirmed in animal models, before suggesting them as complementary and health-promoting compounds. It is also recommended to optimize the hydrolysis conditions to reach the sample with maximum efficiency in vitro, and to use the sample with the highest antioxidant or cytotoxic activity in subsequent investigations to observe the maximum efficiency in animal models. After obtaining promising results in animal and human studies and the necessary approvals, antioxidant and cytotoxic protein hydrolysate can be commercially produced and used as functional compounds.

\section{CONCLUSION}

Production of protein hydrolysates from Klunzinger's mullet represented an alternative way of upgrading this species. The antioxidant and cytotoxic properties of klunzinger's mullet protein hydrolysates showed that these hydrolysates present potential as a functional food ingredient or as natural food supplement.

\section{REFERENCES}

Alemán A, Giménez B, Pérez-Santin E, Gómez-Guillén M, Montero P. Contribution of Leu and Hyp residues to antioxidant and ACE-inhibitory activities of peptide sequences isolated from squid gelatin hydrolysate. Food Chem. 2011a;125(2):334-341.

Alemán A, Pérez-Santín E, Bordenave-Juchereau S, Arnaudin I, Gómez-Guillén M, Montero P. Squid gelatin hydrolysates with antihypertensive, anticancer and antioxidant activity. Food Res Int. 2011b;44(4):1044-1051.

AOAC. Official Method of Analysis. 16th Ed. Association of Official Analytical Chemists. Washington, USA; 1995.

Bamdad F, Wu J, Chen L. Effects of enzymatic hydrolysis on molecular structure and antioxidant activity of barley hordein. J Cereal Sci. 2011;54(1):20-28.
Bougatef A, Nedjar-Arroume N, Manni L, Ravallec R, Barkia A, Guillochon D, Nasri M. Purification and identification of novel antioxidant peptides from enzymatic hydrolysates of sardinelle (Sardinella aurita) by-products proteins. Food Chem. 2010;118(3):559-565.

FAO. Global Aquaculture Production Statistics. 2016.

Faine LA, Rodrigues HG, Galhardi CM, Ebaid GM, Diniz YS, Fernandes AA, Novelli EL. Butyl hydroxytoluene (BHT)induced oxidative stress: effects on serum lipids and cardiac energy metabolism in rats. Exp Toxicol Pathol. 2006;57(3):2216.

Girgih AT, He R, Hasan FM, Udenigwe CC, Gill TA, Aluko RE. Evaluation of the in vitro antioxidant properties of a cod (Gadus morhua) protein hydrolysate and peptide fractions. Food Chem. 2015;173:652-659

Giri A, Ohshima T. Bioactive marine peptides: Nutraceutical value and novel approaches. Adv Food Nutr Res. 2012;65:73105.

Girgih AT, He R, Hasan FM, Udenigwe CC, Gill TA, Aluko RE. Evaluation of the in vitro antioxidant properties of a cod (Gadus morhua) protein hydrolysate and peptide fractions. Food Chem. 2015;173:652-659.

Guo G, Hou H, Li B, Zhang Z, Wang S, Zhao X. Preparation, isolation and identification of iron-chelating peptides derived from Alaska pollock skin. Process Biochem. 2013;48(1):988993.

Harnedy PA, FitzGerald RJ. Bioactive peptides from marine processing waste and shellfish: A review. J Funct Foods. 2012;4(1):6-24.

Hsu KC, Li-Chan EC, Jao CL. Antiproliferative activity of peptides prepared from enzymatic hydrolysates of tuna dark muscle on human breast cancer cell line MCF-7. Food Chem. 2011;126(2):617-622.

Kiabi BH, Abdoli A, Naderi M. Status of the fish fauna in the South Caspian Basin of Iran. Zool Midd East. 1999;18(1):57-65.

Kim SK, Mendis E. Bioactive compounds from marine processing byproducts-a review. Food Res Int. 2006;39(4):383393. 
Kumar NS, Nazeer R, Jaiganesh R. Purification and biochemical characterization of antioxidant peptide from horse mackerel (Magalaspis cordyla) viscera protein. Peptides. 2011;32(7):14961501.

Leung $\mathrm{EH}, \mathrm{Ng} \mathrm{T}$. A relatively stable antifungal peptide from buckwheat seeds with antiproliferative activity toward cancer cells. J Peptide Sci. 2007;13(11):762-7.

Liu Q, Kong B, Xiong YL, Xia X. Antioxidant activity and functional properties of porcine plasma protein hydrolysate as influenced by the degree of hydrolysis. Food Chem. 2010;118(2):403-410.

Marcela GM, Eva RG, del Carmen RRM, Rosalva ME. Evaluation of the antioxidant and antiproliferative effects of three peptide fractions of germinated soybeans on breast and cervical cancer cell lines. Plant Foods Hum Nutr. 2016;71(4):368-74.

Mendis E, Rajapakse N, Byun H-G, Kim SK. Investigation of jumbo squid (Dosidicus gigas) skin gelatin peptides for their in vitro antioxidant effects. Life Sci. 2005;77(17):2166-2178.

Menrad K. Market and marketing of functional food in Europe. J Food Eng. 2003;56(2-3):181-188.

Nikoo M, Benjakul S, Ehsani A, Li J, Wu F, Yang N, Xu X. Antioxidant and cryoprotective effects of a tetrapeptide isolated from Amur sturgeon skin gelatin. J Funct Foods. 2014;7:609620.

Nikoo M, Benjakul S. Potential application of seafood-derived peptides as bifunctional ingredients, antioxidant-cryoprotectant: A review. J Funct Foods. 2015;19(Part A):753-764.

Noda N, Wakasugi H. Cancer and oxidative stress. Jp Med Assoc J. 2001;44(12):535-539.

Picot L, Bordenave S, Didelot S, Fruitier-Arnaudin I, Sannier F, Thorkelsson G, Piot J. Antiproliferative activity of fish protein hydrolysates on human breast cancer cell lines. Process Biochem. 2006;41(5),1217-1222.

Phanturat P, Benjakul S, Visessanguan W, Roytrakul S. Use of pyloric caeca extract from bigeye snapper (Priacanthus macracanthus) for the production of gelatin hydrolysate with antioxidative activity. LWT-Food Sci Technol. 2010;43(1):8697.
Pownall TL, Udenigwe CC, Aluko RE. Amino acid composition and antioxidant properties of pea seed (Pisum sativum L.) enzymatic protein hydrolysate fractions. J Agric Food Chem. 2010;58(8):4712-4718.

Raghavan S, Kristinsson HG. Antioxidative efficacy of alkalitreated tilapia protein hydrolysates: a comparative study of five enzymes. J Agric Food Chem. 2008:56(4):1434-1441.

Raghavan S, Kristinsson HG, Leeuwenburgh C. Radical scavenging and reducing ability of tilapia (Oreochromis niloticus) protein hydrolysates. J Agric Food Chem. 2008;56(21):10359-10367.

Sarmadi BH, Ismail A. Antioxidative peptides from food proteins: a review. Peptides. 2010;31(10):1949-1956.

Shahidi F, Alasalvar C. Marine oils and other marine nutraceuticals. Handbook of seafood quality, safety and health applications. Oxford: Wiley-Blackwell; 2011, p. 444-454.

Terry P, Lagergren J, Ye W, Nyrén O, Wolk A. Antioxidants and cancers of the esophagus and gastric cardia. Int J Cancer. 2005;87(5):750-754.

Theodore AE, Raghavan S, Kristinsson HG. Antioxidative activity of protein hydrolysates prepared from alkalineaided channel catfish protein isolates. J Agric Food Chem. 2008;56(16):7459-7466.

Tothilla P, Klys HS, Matheson LM, McKay K, Smyth JF. The long-term retention of platinum in human tissues following the administration of cisplatin or carboplatin for cancer chemotherapy. Eur J Cancer. 1992;28(8-9):1358-1361.

Venugopal V. Marine products for healthcare: functional and bioactive nutraceutical compounds from the ocean. Boca Raton: CRC Press; 2008.

Witschi HP. Enhanced tumour development by butylated hydroxytoluene (BHT) in the liver, lung and gastro-intestinal tract. Food Chem Toxicol. 1986;24(10):1127-1130.

Received for publication on $21^{\text {st }}$ April 2018 Accepted for publication on $03^{\text {th }}$ August 2018 